REDES- Revista hispana para el análisis de redes sociales

Vol. 18,\#13, Junio 2010

http:// revista-redes. rediris.es

\title{
Power from Switching across Netdoms through Reflexive and I ndexical Language
}

\author{
Jorge Fontdevila ${ }^{1}$, Department of Sociology, California State University Fullerton \\ Harrison C. White, Department of Sociology, Columbia University
}

\begin{abstract}
In differentiated societies with far-reaching yet fragmented social networks, the ability to manage pervasive ambiguity is crucial to navigate domination orders. In this paper we contend that identities, to enhance their control through switchings across networks and domains (netdoms), manage growing ambiguity via language's reflexive and indexical features. We elaborate on several features-metapragmatics, heteroglossia, and poetics-and assert that they are seldom innocent performances to build consensus in the reproduction of social orders. On the contrary, language is inherently implicated in relations of domination. We then argue that metapragmatic control of stories acquired in countless netdom switchings leads to strong footings that secure resources and opportunity; that rhetorics that include rich heteroglossic voicing via structural holes generate stories that can be reflexively transposed to other institutional arenas; and that poetic control of speech styles may transform identities into power-law constellations with robust footing that decouple into prisms to preserve quality. Our goal is to twofold: First, to show that the reflexivity and indexicality of language emerges from myriad switchings across netdoms; and second, to demonstrate that reflexive and indexical language is critical to identities' struggles for control-of footing and domination-via their switchings across rapidly polymerizing netdoms.
\end{abstract}

Key words: Identity, Social Network, Indexicality, Power, Language.

\section{Resumen}

En sociedades diferenciadas con redes sociales de largo alcance pero fragmentadas, la habilidad de manejar la ambigüedad es crucial para navegar órdenes dominantes. En este artículo sostenemos que las identidades, para aumentar su control a través de cambios de redes y dominios (netdoms), manejan una ambigüedad creciente a través de las propiedades indéxicas y reflexivas del lenguaje. Explicamos varias propiedades-metapragmática, heteroglosia, y poética-y afirmamos que éstas rara vez constituyen actuaciones inocentes de creación de consenso en la reproducción de los órdenes sociales. Al contrario, el lenguaje está inherentemente implicado en relaciones de dominación. Así, argumentamos que el control metapragmático de historias adquiridas en incontables cambios de netdoms conduce a posiciones firmes que aseguran recursos y oportunidades; que las retóricas que incluyen fértiles voces heteroglósicas a través de agujeros estructurales generan historias que se pueden transponer reflexivamente a otras arenas institucionales; y que el control poético de estilos lingüísticos puede transformar identidades en leyes potenciales con posiciones que se desacoplan en prismas para preservar su calidad. Nuestra meta es doble: Primero, mostrar que la reflexividad e indexicalidad del lenguaje emergen en multitud de cambios a través de netdoms; y segundo, demostrar que el lenguaje

\footnotetext{
${ }^{1}$ Enviar correspondencia a: Jorge Fontdevila (jfontdevila@fullerton.edu).
} 
REDES- Revista hispana para el análisis de redes sociales

Vol. 18,\#13, Junio 2010

http: // revista-redes. rediris.es

indéxico y reflexivo es crítico en las luchas de las identidades por el control-de posiciones y dominación-a través de cambios de netdoms que se polimerizan rápidamente.

Palabras Clave: Identidad, Red Social, Indexicalidad, Poder, Lenguaje

\section{I ntroduction}

In highly differentiated societies with far-reaching yet fragmented social networks, such as post-industrial societies, the ability to manage and sustain pervasive ambiguity in daily interactions is crucial to navigate domination orders. Identitiesfrom individuals to organizations-struggle to reflexively control decoupling and contradictory demands through switchings across entangled social networks and interpretive domains (hereafter netdoms). ${ }^{2}$ At times strong interactional footings or other competitive edges may emerge through successful albeit temporary juggling of disjointed framings across netdom switchings. Moreover, to manage mounting ambiguity and contradiction across rapidly polymerizing netdoms skillful innuendo and indirect language is used. Thus increasing netdom complexities in contemporary societies seem to proceed along ever more virtuoso meta-communicative performances that can reframe volatile and unpredictable mutual expectations (e.g., workplaces with downsizing risks, job markets following fickle trends, gender relation uncertainties, fast-paced multicultural daily interactions). We in the $21^{\text {st }}$ century inhabit social worlds that are sustained by fleeting arts of phenomenological epoché in connection with rapidly shifting netdom configurations.

\section{Language, Meaning, and Control}

Language is unique because of its reflexive capacity. It is used to talk about itself and describe its own structure and uses, to report either directly or indirectly earlier utterances of other speakers, to indicate shifting speakers' roles, and to reflexively label the mutable existence of conventionalized entities by the use of so-called proper names. In all such instances, through its pervasive reflexivity, language itself serves as a guide for interacting speakers to meaningfully interpret and frame their own linguistic utterances.

Language is also used to index: for instance, aspects of context or narrative events. A significant turning point in the understanding of reflexive framing and context in

\footnotetext{
${ }^{2}$ Netdoms bridge the separate abstractions of social network and cultural domain. Networks and domains merge in type of tie delivering a set of stories and a characteristic sense of temporality (White 1995a, 1995b, 1995c, 1992, 2008; Godart and White 2010).
} 
REDES- Revista hispana para el análisis de redes sociales

Vol. 18,\#13, Junio 2010

http: // revista-redes. rediris.es

language use came about when Peirce (1931) foregrounded the indexical dimension of the linguistic sign. Linguistic indexes in contrast to referential symbols are signs or aspects of signs that do not represent but point to the world in order to create or reproduce the social contexts in which they are uttered.

In this paper we argue that some identities, to enhance their control in the face of shifting netdom demands and rapid decouplings, contextualize and manage growing ambiguity and contradiction through language's reflexive and indexical features. Another paper (Godart and White 2010) suggests that high ambiguity of sociocultural context can induce a self-reproducing syncopation of process, a style that shapes language features. A third paper (Mohr and White 2008) shows how disciplined and multi-level socio-cultural formations can stabilize around institutions of meaning.

Meaning, rather than residing in semantics, emerges reflexively between grammars and participants' interactional hard work at indexically framing ongoing speech situations. Meaning in language is thus an interactional accomplishment of identities seeking control and thereby, we will argue, inducing and reproducing patterns of power.

\section{Indexes}

From spatial or temporal locatives (e.g., this, that, now), personal pronouns (e.g., I, you, they), and verb tenses, to code-switching, switching professional registers, humor styles or voice tones, etc., indexes anchor the linguistic code in real contexts of use, rendering language fully operational in communicative practice. According to Silverstein (1976), indexes can be classified along a continuum defined by two analytical dimensions. On one dimension indexes can be placed according to whether they carry more or less traces of referential or semantic content. For example, with respect to the indexical locatives "this" and "that" there is a sense by which they carry some rudimentary semantic content about proximal versus distal relationships to the world despite their "shifting" meanings across different pragmatic contexts. On the other dimension, indexes can be classified according to the degree to which their pragmatic use presupposes (reflects) or performs (creates) the extra-linguistic context that is being signaled out. Thus when several coworkers explain to each other a job-related task using slang or informal language and then suddenly revert back to technical language because they realize their boss is within earshot, their switching registers reflects or presupposes institutionalized work-place relationships 
REDES- Revista hispana para el análisis de redes sociales

Vol. 18,\#13, Junio 2010

http:// revista-redes. rediris.es

via the indexing of the appropriate technical register. However, note that if some coworkers were to continue using an informal register before their boss new creative realignments and authority challenges could arise in need of further negotiation among all hierarchies involved. ${ }^{3}$

Indexes not only presuppose or reflect a social context but can also create the very nature of the social relationships involved in the interaction. For example, by switching from last to first-name basis when addressing an acquaintance, an individual can create a new context of familiarity likely to bring about fresh realignments in a relationship. Many languages, like Javanese, include complex deference and status indexes that can signal or create status differences on the spot by stylistic switches of distinctive lexical choices and grammatical variations (Geertz 1960; Uhlenbeck 1970; Irvine 1985). In short, indexes are more or less codified linguistic elements or strategies that lay out the contextual parameters in which extra-linguistic interactions take place, signaling or constituting the very nature of the social relationships involved (Fontdevila 2010).

\section{Reflexive I ndexicality}

In the wake of Peirce's intellectual breakthrough other important traditions have also explored the indexical capacity of language to create and frame social context: From metalingual or metapragmatic functions of discourse (Jakobson 1960; Volosinov 1973; Bakhtin 1981; Silverstein 1976, 1993), metacommunication (Bateson 1985; Goffman 1974, 1981; Gumperz 1982, 1992a; Hymes 1964, 1972), to phenomenological accounting of social interaction (Schutz 1970; Garfinkel 1967; Sacks, Schegloff, and Jefferson 1974; Cicourel 1985), a plethora of analytical tools and concepts have been developed-indexicality, footing, frame, contextualization cues, discourse strategies and markers, reported speech, voicing, performativity, narrative and narrated events, dialogical, heteroglossia, poetic function, ethnopoetics, embedding, participation frameworks, audience, principal, originator, primary and secondary publics. They emphasize the capacity of participants in linguistic interaction to point to (index) multiple layers of contextual cues, either

\footnotetext{
${ }^{3}$ An extreme case of presupposing indexicality that signals context without changing referential content exists among some Australian aboriginal languages where a complete switch in vocabulary takes place when speakers are within earshot of their mother-in-law or equivalent affines. Such "mother-in-law" language, which simply points to the presence of an "affine" audience in the surroundings, is semantically identical to the standard lexicon but serves as a kind of "affinal taboo" index within the speech situation (Dixon 1972).
} 
REDES- Revista hispana para el análisis de redes sociales

Vol. 18,\#13, Junio 2010

http:// revista-redes. rediris.es

intentionally or unintentionally, that create or reproduce nested interpretative framings for mutual understanding. We next elaborate on several, before turning specifically to patterning of power.

\section{Metapragmatics}

Reflexive activities occur continuously in social interaction to index and structure ongoing linguistic practice and meaning. Silverstein (1976), drawing on Jakobson's insights on the ubiquitous metalingual function of language (i.e., language about language, about the linguistic code), claims that most of the reflexive capacities of language are essentially metapragmatic, that is, most meta-linguistic activities are not about semantic understanding but primarily about the pragmatic use of language in interaction. In this sense, those parts of a meta-language which deal with semantics-metasemantic claims about propositional truth, glossing, and crosslanguage translation-are simply a special subcase of the more general and pervasive metapragmatic function of language. Some explicit examples where the metapragmatic function of language becomes indexically articulated by speakers are: “...don't you dare use that tone with me!!," “Oh, don't call me Sir, you can call me by my first name," "I was careful to use polite language to avoid any extra tensions," or “... my guest overdid it when he said: 'Could you pass me the salt, please? That would be absolutely awesome!'" Note that when language is used to talk about language it is also used to negotiate or re-define the relative interactional footings of all speakers involved in a participation framework. Thus we can force ourselves metapragmatically on a hearer by uttering a direct imperative assuming any social costs (e.g., I repeat: "CLOSE the window!!"), or we can index through indirect speech the meta-communicative message that we respect the hearer's autonomy to act otherwise (e.g., It's kind of chilly in here, is that window broken by any chance?). With various levels of conscious awareness we always use language metapragmatically, that is reflexively, to cultivate our social ties.

Moreover, when some speakers depart from tacitly agreed ways of using a language (e.g., departures of formal register during a corporate deal) others may index their upset through a "metapragmatic attack" (e.g., "Let's keep it professional and leave the jokes for later!") to reset the nature of their established social tie (Jacquemet 1994, 1996 for metapragmatic attacks). In sum, speakers do not passively decode their ongoing utterances against a backdrop of culturally reified contexts but instead 
REDES- Revista hispana para el análisis de redes sociales

Vol. 18,\#13, Junio 2010

http:// revista-redes. rediris.es

use their own face-to-face linguistic interactions as metapragmatic indexes to organize and create their shifting interpretive contexts.

\section{Heteroglossia}

An important body of research dealing with the actual processes that take place when language is used reflexively to talk about itself comes from the Bakhtin tradition of literary studies. After the Russian revolution of 1917, the Bakhtin circle (Bakhtin 1986, 1981, 1983, 1984; Volosinov 1973), drawing on the "early" Marx of the philosophy of praxis, launched a definitive critique of the Saussurean notion of language as an abstract semiotic system removed from social practice. According to Volosinov, "language acquires life and historically evolves ... in concrete verbal communication, and not in the abstract linguistic system of language forms, nor in the individual psyche of speakers" (1973:95). This Russian school strongly opposed the "isolated monologic utterance" and its passive reception, and instead put forth the idea that linguistic utterances are organized dialogically. By dialogical, these scholars meant that language, far from being an abstract and self-contained medium, is typically embedded in an intricate social matrix where the production of any single utterance is already a juxtaposition of multiple "voices" or different points of view drawn from, and invoking, different and alternative culturally and socially lived spheres. This heterogeneous voicing or heteroglossia is expressed through a speaker's utterance by the interpenetration of several social "consciousness," none of which objectifies each other but rather co-exist in a kind of rich heteroglossic dialogue (Bakhtin 1981, 1984). ${ }^{4}$

Addressivity. Moreover, a constitutive characteristic of all utterances is that they anticipate the active, rather than passive, understanding of someone else. In other words, utterances have a certain addressivity built into them. The addressee can be a concrete participant or any abstract audience, including the un-concretized "selfother" of an internal conversation. According to Bakhtin, "both the composition and, in particular, the style of the utterance depend on those to whom the utterance is addressed, how the speaker senses and imagines his addressees, and the force of their effect on the utterance. Each speech genre in each area of speech communication has its own typical conception of the addressee, and this defines it as a genre" (Bakhtin 1986:95). In other words, it is the speaker's orientation toward

\footnotetext{
${ }^{4}$ In this line, it is worth noting that for Bakhtin the novel, a historically late form of literary production that incorporates a multiplicity of genres-voices-in its composition, is considered to be the quintessential expression of the modern consciousness.
} 
REDES- Revista hispana para el análisis de redes sociales

Vol. 18,\#13, Junio 2010

http:// revista-redes. rediris.es

different classes of addressees or audiences that shape and define utterances as token expressions of various styles or genres of speech. Thus, both the complete sentence and the lexicon as linguistic units of thought lack real communicative expression per se, since only the utterance form is constituted with the practical understanding of the other(s) in the horizon and hence can elicit an active communicative response. In short, for the Bakhtin school the utterance is the actual unit of speech communication, capable of coordinating addresser and addressee in order to accomplish the tasks of the social.

Grammar. For this Russian literary tradition, grammar and stylistics, though analytically distinct, cannot be mechanically reduced to one another and ought to be "organically" combined in their study. In this view, any grammatical choice is ultimately a stylistic act. And any stylistic act, in turn, is influenced or regulated by the repertoire of patterns that have assumed grammatical shape and function in the language over different periods of time. In other words, change in language occurs always at the boundaries between grammar and stylistics. A boundary which is fluid and ambiguous "because of the very mode of existence of language, in which, simultaneously, some forms are undergoing grammaticalization while others are undergoing degrammaticalization" in the selective choice of particular styles and genres appropriate to the social situation (Volosinov 1973:126). Only by analyzing the utterance as an expressive form of typified speech genre varieties which converge and diverge in their grammars and styles according to the pragmatics of social life can the whole of the language phenomenon be understood.

Embedding reported speech. A significant topic of inquiry pursued by the Bakhtin circle has been the area of reported speech in conversational and literary discourse and the reflexive potential that exists in framing events and voices when an utterance becomes embedded within another utterance (Volosinov 1973). All languages have verbs of speaking (verbum dicendi), such as "she said ...," or "he asked ...," among others, which can be used metapragmatically to frame and report other speech events occurring in different times and places. Two prototypical styles of reporting, direct and indirect quotation, can be manipulated in order to achieve a variety of social ends. On the one hand, direct quotation (e.g., "he said: 'I am sick and tired of your attitude!'") is indexically anchored to the reported event and has no grammatical relationship to the reporting event-the agent or the time of the reported event is different from the reporter or reporting event. On the other hand, 
REDES- Revista hispana para el análisis de redes sociales

Vol. 18,\#13, Junio 2010

http: // revista-redes. rediris.es

indirect quotation (e.g., "he said that he disliked his attitude") is indexically anchored in the reporting event and hence the reported speech must be formally related to the reporting event by grammatical rules of concordance. Though the subtleties of these reflexive linguistic devices cannot be explored here, suffice it to say that direct quotation can be used to convey vivid and authoritative objectivity to the reported speech event by diffusing agential responsibility of the reporter whereas indirect quotation can eliminate aspects of the original event that the reporter does not want to emphasize. Put another way, by skillful alternation of direct and indirect speech forms the reporter's voice can "infiltrate or manipulate" the voice or point of view of the reported speech event. ${ }^{5}$

\section{The Poetic Function}

The legacy of the Bakhtin school, with its emphasis on reflexive and indexical devices such as reported speech, has become evident in a growing body of research known as performance-based studies and ethnopoetics (Bauman and Briggs 1990; Bauman 1982, 1989; Briggs 1988; Fine 1984; Limon and Young 1986; Stoeltje and Bauman 1988). These studies take seriously Jakobson's insights on the poetic function of language as also being pervasive in everyday talk. While the metalingual function (see above) treats the linguistic code as its own referent, the poetic function manipulates the formal features of the code to call attention to its own stylistic organization and aesthetically persuasive possibilities. For example, in ordinary language we say "innocent bystander" rather than "uninvolved onlooker" because its rhythmic pattern is more aesthetically pleasing (Fiske 1990:36). For these schools, a linguistic performance or the enactment of the poetic function, far from epiphenomenal and derivative, is a highly reflexive mode of communication which is constitutive of what makes ordinary language functional in social life. According to Bauman and Briggs, "performance is seen as a specially marked, artful way of speaking that sets up or represents a special interpretive frame within which the act of speaking is to be understood" (1990:73). They mention that this interpretive frame includes cues, mannerisms or subtle "keys" that mark shiftings in performances, such as voice modulation, posture, gesture, side remarks, and also the dynamic interaction that takes place between performers and audiences, among other things. Moreover, through creative poetic play of figurative and metaphorical speech, quotation, proverbs, riddles, jokes, rhymes, insults, greetings, gossip,

\footnotetext{
${ }^{5}$ Volosinov (1973:141-159) mentions yet a third form of reported speech, the quasi-direct speech, which incorporates peculiarly Western expressive and experiential possibilities.
} 
REDES- Revista hispana para el análisis de redes sociales

Vol. 18,\#13, Junio 2010

http: // revista-redes. rediris.es

innuendo, and various oratorical and rhetorical genres, as well as many other formal features of ordinary conversation, utterances can reframe contexts and signal metamessages that may be quite tangential to their actual referential contents.

\section{Patterns of Power across Netdom Switchings}

We argue that the use of reflexive and indexical devices during interaction is seldom an innocent performance to build consensus in the reproduction of social orders. On the contrary, the reflexive and indexical capacities of language are typically asymmetrical and inherently implicated in relations of domination and conflict. Whether relatively captured by the analytical tools of hegemony (Gramsci 1971), oppositional cultures (Williams 1977), discursive power (Foucault 1978, 1980), or linguistic capitals (Bourdieu 1977, 1991), indexical and reflexive phenomena are never universally available to all members of society and are produced, circulated, and accumulated unequally in a "political economy" of linguistic exchanges. Like Bourdieu who claims that power lies at the center of social life, White also sees domination as "the root process in what is specifically social" (White 1995a:10; 1995b, 1995c).

Bourdieu (1977, 1991) more specifically has theorized the "materiality" of the linguistic sign through his concept of the linguistic market place. ${ }^{6}$ In his view, because linguistic practices are involved in providing access to material resources they become a resource in their own right. In short, language in being an instrument of communication is also an instrument of power.

\section{Grammaticalization}

Language-which is always discourse of various genres, sublanguages, styles, and registers-is laden at all scales with struggles for domination and identity. Against developmental theories of grammar as co-textual and semantic "routinization" (Hopper and Traugott 1993), we see grammaticalization in language as the cumulative traces over time of radical historical discontinuities and struggles for identity and control among netdoms, and see grammatical rules as the historical expression of these cumulative patterns that in turn shape further options of netdom switching variabilities. ${ }^{7}$ Thus, grammars build around a limited set of referential and

\footnotetext{
${ }^{6}$ But see Gal 1987, 1989, and Irvine 1989 for finer theoretical elaborations of the linguistic market place.

${ }^{7}$ See Lodge 1993 for the contentious origins of French grammar, for example.
} 
REDES- Revista hispana para el análisis de redes sociales

Vol. 18,\#13, Junio 2010

http:// revista-redes. rediris.es

indexical items, a semi-closed class of surface categories of deixis (e.g., he, that, now, here), verb forms, syntax orders, conjunctions, pronouns, and relativizers, etc., that more so than the open classes of lexicons and vocabularies, express the historical struggles over discourses (control) and styles (identity) that eventually become congealed in a language.

Put another way, grammar is routinization, but by domination rather than innocent habituation, over choices of switchings among unequal social networks and interpretive domains. In this respect, we call on the insights of the sociolinguistics of pidgins and creoles as models for localized grammaticalization processes intrinsically embedded in relations of domination, and adapt them to any pragmatic situation where actors, fluent in different sublanguages and indexical subsystems, are forced to interact in a common lingua franca-thus not only trade posts and plantations, but multi-ethnic job places in any modern organization traversed by global networks of transactions and peoples as well. In other words, it is important to understand how grammaticalization, for example of social deixis in the modern corporation, results from multiple nested levels of registers and linguistic capitals that interact through various domination interfaces and netdom switchings of transposed "lexifier acrolects," various in-between "mesolects," and foundational "basilects" (Hymes 1971; Sankoff and Brown 1976; Sankoff 1980; Holm 1988; Fasold 1990; Bailey and Maynor 1987).

\section{Netdom Switchings}

Far from egalitarian and universal patternings, switches among netdoms are seized and shaped differently according to social positionings in struggles over semiotic and material control. We argue that to become fully operational the reflexive notions of multiple voicing or "genre" heteroglossia a la Bakhtin need to be radically embedded not in multiple layers of phenomenological and creative "blendings" but rather in tangible and reflexive network "switchings." In this we follow Halliday's vision that speech registers and meanings originate from switchings among sets of alternative options inextricably linked to social activities and functional settings (Halliday 1973, 1976, 1978, 1985; Dejoia and Stenton 1980; Swales 1990). We will go on to assert that the reflexivity (switching) of language is essentially about managing ambiguity. But ambiguity should not be removed methodologically as measurement error but should become fully integrated into the analytical model via appropriate functions and parameters. 
REDES- Revista hispana para el análisis de redes sociales

Vol. 18,\#13, Junio 2010

http: // revista-redes. rediris.es

When observed in successive snapshots, netdom switchings appear like "zaps" between TV channels or "Schutzian shocks" in phenomenological jargon (Shutz $1970)$. In this sense, we agree with Silverstein $(1979,1993)$ that most of what we experience as orderly discourse would be chaotic if it were not for continuous reflexive and meta-discursive hard work. However, contrary to Silverstein's "heroics of indexicality" apparently replicated in every face-to-face situation, we maintain that phenomenological repair and metapragmatic work need not be in "myopic messiness of dyads" but rather channeled by broader social impositions, such as disciplines and control regimes, and other spatiotemporal patterns.

Thus language is always discursively inter-animated by both social networks and domains, and its characteristic reflexivity is attained through myriad switchings that offer opportunity as well as constraint, and are as indexical as they are localized in social space and domination. Together networks and domains merge in type of tie, delivering a set of stories and a characteristic sense of lived temporality. Switches in talk between different domains are at the same time switches in which particular social ties and respective stories of different sorts are being activated and deactivated. Language thus originates in reflexive transitions between domains that are bound up necessarily with transitions among hierarchical networks.

In short, the metapragmatics of netdom switches is a profoundly social rather than cognitive activity-dyadic interaction or the face-to-face still being a euphemism for the cognitive. Thus, first comes the social with specializations of "work" and "rank" (primordial "speech registers"), and only after enough power and complexity develops can a variety of speech forms sustain indexicality through switchings. Note that we are moving here beyond the debates that try to explain the referential from the indexical function of language (semantics from pragmatics) since we take it one step further and explain the indexical from the relational via differentiated switchings (pragmatics from social scope and network): "networks and domains in their interpenetration as network-domains allow one to locate social chains and waves of interpretive consequence, to which dyadic analysis-or purely cultural and cognitive interpretation, or purely social network connectivity-is blind" (White 1995b:8). And to trace such "interpretive resonances at various removes" requires characterizing spatiotemporal patterns of domination and other polymerizing constellations among netdoms. 
REDES- Revista hispana para el análisis de redes sociales

Vol. 18,\#13, Junio 2010

http: // revista-redes. rediris.es

\section{Managing Ambiguity}

I dentities-individual or collective-emerge from persistent efforts to seek control in their turbulent and uncertain surroundings (White 2008; White, Godart, and Corona 2007; Godart and White 2010). ${ }^{8}$ In their struggles for control, some identities attain more robust and lasting netdom positionings through social footings that must be reflexive. Thus ongoing reflexivity is critical to sustain and manage ambiguity so that identities can quickly anticipate and re-frame switches through rapidly polymerizing and decoupling netdoms. Emerging and robust footings from a set of related identities shape in turn netdom landscapes for other identities in their struggles for control.

Viable identities produce reflexive accounts and stories about their netdom ties and cliques that remain indexically open to ever changing contingencies and participation frameworks. In fact, we contend, contra Luhmann, that navigating uncertainty in social life is not so much about stabilizing expectations of isolated dyads to resolve their double contingency but rather about skillful and open juggling of expectation sets across the multiple contingency of shifting netdom configurations (White 2007). In light of the significance of reflexive language in controlling and managing ambiguity, we discern three emergent phenomena among netdoms that are constitutive of identities-stories, rhetorics, and styles.

\section{Stories through Metapragmatic Control}

In their struggle to secure social footing identities reconfigure netdoms by establishing or breaking ties with other identities. In the process they spark meanings that "coalesce into stories" (Godart and White 2010:10). Stories relate meanings and events into reflexive and transposable patterns. They are key in the generation of identities since social ties within participation frameworks are typically expressed and interpreted through stories. Stories deliver a characteristic sense of continuity and lived temporality to relationship ties, which otherwise would switch on and off in everyday disjointed snapshots. Moreover, stories can be organized in story-lines that provide identities with more or less coherent ex post accounts of

\footnotetext{
${ }^{8}$ It is important to clarify that "control" is not necessarily about "domination over other identities. Before anything else, control is about finding footings among other identities. Such footing is a position that entails a stance, which brings orientation in relation to other identities" (White 2008:1). In this sense, footing is a "search for perduration, but what perduration entails varies-from sheer survival to imposition of one's will, so that attempts at control are not limited to coercion or domination efforts" (Godart and White 2010:5). Moreover, following March (1994:86) who asserts that actors typically "act within a mix of rules and incentives," we contend that finding footing involves not only means-ends instrumental orientations but moral and ritual stance as well.
} 
REDES- Revista hispana para el análisis de redes sociales

Vol. 18,\#13, Junio 2010

http:// revista-redes. rediris.es

lived turbulences and discontinuities. A story-line is like "a résumé, a postrationalization of a necessarily chaotic social trajectory" (Godart and White 2010: 18).

We contend that the stories and story-lines that circulate across netdoms and that construe identities, ties, and network cliques are seldom symmetrically co-produced by all the speakers of a participation framework. Thus speakers with stronger and durable footings in institutional settings have more metapragmatic influence and heteroglossic control in the Bakhtinian sense to frame the stories that capture their interactions. They are the ones who have a stronger "voice" in the messy coproduction of stories. They manage definitions of situations through greater metapragmatic leverage and invoke speech genres and reported voicings, interactional times and ambiguities, which asymmetrically shape their emerging stories. Moreover, speakers with stronger metapragmatic footings have the power to indexically "entextualize" circulating stories and "close" or "open" their meanings to interpretive ambiguity. ${ }^{9}$ In this sense, who (and how and when) has the power to rewrite stories, tell and retell them, transpose their reflexive indexicalities to new contexts, etc., bears centrally on the social construction of authority. ${ }^{10}$

For example, gatekeepers at different levels of organizational structures who control access to opportunities and resources (e.g., hiring or promotion committees, supervisors, professors, social workers, health professionals, judges) are likely to impose their contextualization cues and metapragmatic rules in their face-to-face interactions. They will set the broad indexical boundaries of the participation framework within which interaction is normatively acceptable, including the right amount and timing for genre switches (e.g., a joke, a humoristic side remark, the telling of an anecdote or proverb), the appropriate tone and prosody, ritual conventions for speakers' turn-takings and silences, politeness formulae and deference, among others (Gumperz, Jupp, and Roberts 1979, Gumperz 1992b for "crosstalk" among multiethnic indexicalities). Moreover, despite the existence of formal criteria (e.g., official job descriptions, labor contracts) to access opportunity in

\footnotetext{
9 "Entextualization" makes reference to all the processes that render discourses detachable from their interactional settings into transposable texts by using reflexive and metapragmatic mechanisms such as indexical grounding, heteroglossia, multiple voicing, reported speech, etc. In this sense the power to decontextualize discourse into congealed texts and then subsequently recontextualize them among different speech participation frameworks and audiences is a fundamental act of political control (Bauman and Briggs 1990).

${ }^{10}$ Here we propose a working definition of netdom power and domination as the enhanced "autonomy" (i.e., more degrees of freedom) of an identity or group of identities to control their interactional footings across netdoms switchings.
} 
REDES- Revista hispana para el análisis de redes sociales

Vol. 18,\#13, Junio 2010

http:// revista-redes. rediris.es

an organization, gatekeepers typically concoct stories and story-lines after their faceto-face interactions that heavily include their own heteroglossic voicings, direct or indirect reportings, metapragmatic upsets and attacks, idiosyncratic addressivities, various framings, and ex post rationalizations as to why actors deserve or not deserve access to such opportunities.

Thus in connection with stories and metapragmatic control, we formulate the following two hypotheses under ceteris paribus conditions:

HYPOTHESIS 1: The more control identities have over opportunities and resources across netdoms, the more likely they are to exert metapragmatic and reflexive control over the co-production of stories that construe the ties of their participation frameworks.

HYPOTHESIS 2: $\quad$ The more metapragmatic and indexical control identities exert in managing interactional ambiguity within their participation frameworks, the more likely they are to increase their control over opportunities and resources across netdoms.

Note that metapragmatic and indexical control involves, among other things, the know-how to keep a conversational tie ongoing through the competent use of microrituals, tact, and other impression repair practices, including when to uphold or reduce indirectness and ambiguity so as to negotiate a sustainable "working consensus" (Goffman 1959, 1967, 1971). In this light, we argue that identities with exceptional metapragmatic framing capacities acquired in myriad netdom switchings can also secure opportunities and resources across netdoms.

\section{Rhetorics through Heteroglossic Voicing}

Rhetorics are folk theories or commonsense understandings that are jointly held and shared by identities interacting in connected netdoms as institutions. Stories draw on background rhetorics to express and construe their ties. In turn, rhetorics "play out through stories" (Mohr and White 2008; Godart and White 2010:25). A rhetoric demarcates a broad interpretive context that becomes "an important building block of an institutional system" (White 2008:177). In this sense, "rhetorics make institutions explicit in cultural contexts" (Godart and White 2010:25). Thus, for example, marriage as an institution is sustained by a rhetoric of committed relations between two consenting adults of any gender in some netdoms, whereas in many others it is sustained by a rhetoric of an exclusive bond between a man and a woman. Rhetorics guide identities across netdom switches by appealing to broader meanings that simplify the messiness of social life, and as the above example about 
REDES- Revista hispana para el análisis de redes sociales

Vol. 18,\#13, Junio 2010

http:// revista-redes. rediris.es

marriage implies, are also rife with "dominations and exclusions" (White 2008:177; Mohr and White 2008).

In this connection, we argue that rhetorics can be mobilized and deployed unequally to get selective action and stories across netdoms. For instance, identities that broker transactions between two or more separate netdoms that are sustained by different rhetorics may gain a competitive edge by learning how to navigate back and forth between those rhetorics, including the production of "hybrid" rhetorics (e.g., a tertius gaudens, a religious missionary who is bilingual and benefits from land mediations between a local chief and a government official, the administrative coordinator of a firm who selectively filters stories based on conflicting rhetorics between staff and management). Moreover, netdoms that include a critical number of structural holes (Burt 1995) can incorporate multiple rhetorics through exposure to heterogeneous voicings and addressivities linked to separate and non-redundant ties. ${ }^{11}$ Heteroglossic rhetorics that draw from a multiplicity of unrelated netdoms and incorporate different points of view enable identities to frame ambiguity in the face of netdom decouplings and change.

In this line, the existence of complex hybrid rhetorics or simply a "repertoire" of rhetorics can give identities the capacity to frame netdom ambiguity and avoid indexically closing meaning to a reduced set of contexts. Only those identities that keep rhetorics reflexively open to other rhetorics can quickly reframe and secure durable footings in changing netdom landscapes; those who rigidly enclose their rhetorics in unreflective boundaries may eventually find themselves in netdom peripheries without any footing.

Furthermore, identities-individual or collective-with robust and durable footings are typically connected to a wide range of diversified ties and netdoms, "much like a multi-legged table on a dais" (White 2007:5; Bothner, Smith, and White 2010). Often they are at the intersection of a number of traversing core netdoms but also supported by the peripheries of many others. Moreover, they may observe distant cores as well. We argue that identities with robust and durable footings that are spread among diversified and non-redundant netdoms and netdom levels have more prospects to become relative outsiders and second-order observers of the various

\footnotetext{
${ }^{11}$ Structural holes become relatively efficient only within certain boundaries. Thus too many (sparsity) or too few (redundancy) structural holes in a network can become functionally equivalent with respect to the lack of external flows of material and cultural resources. This is because "all dots connected" and "no dots connected" carry equally low informational value or resource flow (Burt 1995).
} 
REDES- Revista hispana para el análisis de redes sociales

Vol. 18,\#13, Junio 2010

http:// revista-redes. rediris.es

rhetorics that circulate among them. As second-order observers of other netdoms, these more durable identities become aware of "how" other netdom rhetorics are reflexively constructed, what their commonsensical building blocks are, and whether other rhetorics can be incorporated or manipulated. ${ }^{12}$ Robust identities connected to diversified netdoms have a reflexive edge in seeing other core and peripheral rhetorics for what they are, a social construction, because "[t]hat which appears obvious and necessary to the network appears improbable, variable, and contingent to its outside observers" (Fuchs 2001:39). Moreover, identities with robust footings may not only deconstruct others' rhetorics but also become reflexively aware of their own constructions when they switch back to their cores. In fact, complex back-andforth switching between different observational levels, cores and peripheries, insiders and outsiders, "triggers adventures in reflexivity" (Fuchs 2001:25).

In light of rhetorics with heteroglossic voicing, we formulate the following two hypotheses under ceteris paribus conditions:

HYPOTHESIS 3: The more identities develop robust footings in netdoms with structural holes of diversified and non-redundant ties, the more likely they are to generate or follow rhetorics with rich heteroglossic voicings and addressivities.

HYPOTHESIS 4: The more identities produce stories that draw on rhetorics with rich heteroglossic voicings and addressivities, the more capable they are to reflexively transpose and reframe their stories to secure footing across decoupling netdoms.

\section{Styles through Reflexive Poetics}

Styles are "syncopated complexities" across netdoms that distinguish identities but also may anticipate them (Godart and White 2010; White 2007; White 2008). Styles emerge from identities at different levels of action as ongoing sensibility "that somehow continues its rhythm and harmony despite stochastic variance in particular notes and phrases" (White, Godart, and Corona 2007:197; White 2008). Once a style crystallizes around an identity or group of identities the rhetorics that inform their commonsensical understandings may not deviate too far from it. There are important affinities between styles and rhetorics. In fact, the types of rhetorics that inform an identity through its stories are often delimited indexically by its style.

\footnotetext{
12 According to Fuchs, "outside observers do not observe first-level whats, but second-level hows. They see what cannot be seen from the inside, decomposing the foundational certainties and invisibilities without which the observed network could not do what it does" (2001:39).
} 
REDES- Revista hispana para el análisis de redes sociales

Vol. 18,\#13, Junio 2010

http: // revista-redes. rediris.es

We argue that the poetic function of language is crucial in the production of dominant interactional styles that secure durable footing. The poetic function manipulates the linguistic code to draw attention to its aesthetic and persuasive possibilities. Thus the creative and poetic play exercised by some identities within netdom configurations on figurative and metaphorical speech, cadence and tempo, heroic or humor key, proverbs and riddles, and various oratorical and rhetorical genres gives them a stronger "stylistic" edge. In other words, the agile use of the poetic function gives identities an idiosyncratic "syncopated" sensibility in talk that may have the persuasive ability to secure strong footings among certain netdoms. Some styles are too unyielding and hence upcoming identities with new footings and rhetorics decouple from them to create their own. However, we also argue that other styles tap into netdoms and publics that quasi-transform them into seemingly powerlaw distributions. Thus unique and successful styles often trigger power-law nodes of netdom connections along the lines of imitation, status, or deference. Eventually to avoid stylistic devaluation many identities associated with successful speech styles arrange themselves in "complex prisms" of netdoms that guard their quality and prestige through selective refractions and many more reflective exclusions (Podolny 2001 for networks as prisms). Finally, we know from the Bakhtin School that stylistics and grammars are intertwined, and that any stylistic act has grammatical consequence. In this line, the stylistic control of a language is ultimately also about grammatical control.

In relation to styles and reflexive poetics, we formulate the following two hypotheses under ceteris paribus conditions:

HYPOTHESIS 5: The more identities control the poetic function to stylistically persuade other identities within their participation frameworks, the more likely they are to develop strong and durable footings across netdoms.

HYPOTHESIS 6: The more identities via the poetic function become transformed into stylistic power-law nodes across netdoms, the more likely they will decouple past a threshold into stylistic quality prisms that selectively refract some ties but reflect off many others.

\section{Conclusion}

Emergent identities triggered by rapidly decoupling netdoms cannot survive contingency and turbulence unless they manage pervasive uncertainty and ambiguity. To get "fresh action" of consequence that can secure them strong footing, identities switch across polymerizing netdoms seeking transition phases that lie amid 
REDES- Revista hispana para el análisis de redes sociales

Vol. 18,\#13, Junio 2010

http:// revista-redes. rediris.es

too much and too little social order (i.e., at the "edge of chaos"). In these phase transitions identities are able to incorporate and endure turbulence because they can build ties with supple reflexivity, including myriad framing redundancies that are metapragmatically and indexically easily re-arranged and yet never completely random. Put differently, the reflexive and indexical capacity of language to frame and manage ambiguity across netdom switchings is precisely what keeps ties and stories at the "edge of chaos" and thus key to their survival in everyday life interaction.

Moreover, identities not only seek transition phases to secure footing through reflexive ties but also create themselves such transitions to get fresh action. In other words, some identities in their struggle for control manage to uncongeal rigid ties and bring whole netdoms to the "edge of chaos." For this, exceptional reflexivity across levels is needed. In fact, to unblock and loosen metapragmatic routine and inertia in social life often requires "ingenuities of decoupling and agency that crosscut the stories of disciplines as well as rhetorics and styles and the regimes into which they may cumulate" (White 2008: 283).

In this sense, we assert that identities-individual or collective-that attain certain power and domination in social life, that is, they manage to acquire enhanced autonomy to control their footings across netdom switchings, are also those that have the exceptional know-how to manage pervasive reflexivity and indexicality in the construction of their social ties. In contrast, identities that are too quick to close indexicality may easily find themselves outside networks of power. Put differently, identities with footings in dominant netdoms tend to create stories embracing ambiguity and transposable polysemy that keep their ties flexible in anticipation of change. Thus following Leifer (1991) in his characterization of chess players of tournament quality, we assert that reaching through and across netdoms to get robust action entails "keeping the state of interaction hard to assess through making very many possible evolutions continue to seem possible ... which prevents anyone from seeing clearly an outcome that would end the social tie" (White 2008:288).

In this article we have argued that metapragmatic and indexical linguistic control of ties and their stories acquired in countless switchings of participation frameworks can develop strong footings which, in turn, can secure resources and opportunity across netdoms. We have indicated that institutional rhetorics that incorporate rich and multiple heteroglossic voicing and addressivities through their structural holes produce stories that can be readily and reflexively transposed to other institutional 
REDES- Revista hispana para el análisis de redes sociales

Vol. 18,\#13, Junio 2010

http:// revista-redes. rediris.es

netdoms. Finally, we have claimed that poetic control of speech styles can transform identities into power-law constellations with robust footings that may then decouple into new netdom prisms to preserve quality. In conclusion, our goal has been twofold: First, to show that the reflexivity and indexicality of language emerges from myriad switchings across netdoms; and second, to demonstrate that reflexive and indexical language is critical to identities' struggles for control-of footing and domination-via their switchings across rapidly polymerizing netdoms.

\section{Acknowledgments}

We are grateful to Corinne Kirchner and Matthias Thiemann for their helpful comments and insights.

\section{References}

Bailey, G. and Maynor, N. (1987). "Decreolization?" Language in Society, 16(4): 449 $-74$.

Bakhtin, M. M. (1981). The Dialogical Imagination: Four Essays. M. Holquist (ed.). Austin: The University of Texas Press.

- (1983). Bakhtin School Papers, (eds.) A. Shukman. Russian Poetics in Translation (RPT) N.10.

- (1984). Problems of Dostoevsky's Poetics. (ed.) C. Emerson. Minneapolis, MN: University of Minnesota Press.

- (1986). Speech Genres and Other Late Essays. (eds.) C. Emerson and M. Holquist. Austin: The University of Texas Press.

Bateson, G. (1985). "A Theory of Play and Fantasy," Semiotics: An Introductory Anthology," R. Ignis (ed.). Indiana University Press.

Bauman, R. (1982). "Conceptions of Folklore in the Development of Literary Semiotics," Semiotica 39: 1-20.

- (1989). "American Folklore Studies and Social transformation," Text Perform. Q. 9:175-84.

Bauman, R. and Briggs, C. (1990). "Poetics and Performance as Critical Perspectives on Language and Social Life," Annual Review of Anthropology, 19:59-88. 
REDES- Revista hispana para el análisis de redes sociales

Vol. 18,\#13, Junio 2010

http: // revista-redes. rediris.es

Bothner, M. S., Smith, E. B., and White, H. C. (2010). "A Model of Robust Positions in Social Structure," American J ournal of Sociology (Forthcoming).

Bourdieu, P. (1977). "The Economics of Linguistic Exchanges," Social Science Information, XVI-6:645-667

- (1991). Language and Symbolic Power, (ed.) J. Thompson. Cambridge Polity Press.

Briggs, C. L. (1988). Competence in Performance: The Creativity of Tradition in Mexicano Verbal Art. Philadelphia: University of Pennsylvania Press

Burt, R. (1995). Structural Holes: The Social Structure of Competition. Harvard University Press

Cicourel, A. V. (1985). "Text and Discourse," Annual Review of Anthropology, 14: 159-85

Dejoia, A. and Stenton, A. (1980). Terms in Systemic Linguistics: A Guide to Halliday. New York: St. Martins.

Dixon, R.M.W. (1972). The Dyirbal Language of North Queensland. Cambridge Studies in Linguistics, no. 9. Cambridge University Press.

Fasold, R. (1990). The Sociolinguistics of Language. New York, NY: Blackwell.

Fine, E.C. (1984). The Folklore Text: From Performance to Print. Bloomington: Indiana University Press

Fiske, J. (1990). Introduction to Communication Studies. New York, NY: Routledge Fontdevila, J. (2010) “Indexes, Power, and Netdoms: A Multidimensional Model of Language in Social Action," Poetics (Forthcoming).

Foucault, M. (1978). The History of Sexuality, Volume I: An Introduction. Random House, Inc.

- (1980 [1972]). "Lecture Two: 14 January 1976," Power/Knowledge: Selected Interviews and Other Writings 1972-1977. (ed.) C. Gordon. Pantheon Books.

Fuchs, S. (2001). Against Essentialism: A Theory of Culture and Society. Harvard University Press 
REDES- Revista hispana para el análisis de redes sociales

Vol. 18,\#13, Junio 2010

http:// revista-redes. rediris.es

Gal, S. (1987). "Codeswitching and Consciousness in the European Periphery," American Ethnologist, 14.3:637-53

- (1989). "Language and Political Economy," Annual Review of Anthropology, 18:345-67.

Garfinkel, H. (1967). Studies in Ethnomethodology. Polity Press.

Geertz, C. (1960). The Religion of Java. Glencoe, III.: Free Press

Godart, F. C. and White, H. C. (2010). "Switchings under Uncertainty: The Coming and Becoming of Meanings," Poetics (Forthcoming).

Goffman, E. (1959). The Presentation of Self in Everyday Life. Anchor Books.

- (1967). Interaction Ritual: Essays on Face-to-Face Behavior. Anchor Books.

- (1971). Relations in Public: Microstudies of the Public Order. Basic Books Publishers.

- (1974). Frame Analysis. New York: Harper \& Row.

- (1981). Forms of Talk. Philadelphia, PA: University of Pennsylvania Press.

Gramsci, A. (1971). Selection from the Prison Notebooks. New York: International Publishers.

Gumperz, J. (1982). Discourse Strategies. Cambridge University Press.

- (1992a). "Contextualization and Understanding," Rethinking Context: Language as an Interactive Phenomenon, (eds.) A. Duranti and C. Goodwin. Cambridge University Press.

- (1992b). "Interviewing in Intercultural Settings," Talk at Work, (eds.) P. Drew and J. Heritage. Cambridge University Press.

Gumperz, J., Jupp, T. C. and Roberts, C. (1979). Crosstalk: A Study of Cross-Cultural Communication. (National Centre for Industrial Language Training in association with the $\mathrm{BBC})$.

Halliday, M.A.K. (1973). Explorations in the Functions of Language. Elsevier NorthHolland, Inc.

- (1976). Halliday: System and Function in Language. (ed.) G.R.Kress. London: Oxford University Press. 
REDES- Revista hispana para el análisis de redes sociales

Vol. 18,\#13, Junio 2010

http:// revista-redes. rediris.es

- (1978). Language as Social Semiotic: The Social Interpretation of Language and Meaning. London: Edward Arnold Publishers

- (1985). An Introduction to Functional Grammar. London: Edward Arnold Publishers

Holm, J. (1988). Pidgins and Creoles. Cambridge University Press.

Hopper, P. and Traugott, E. (1993). Grammaticalization. Cambridge University Press.

Hymes, D. (1964). "Introduction: Toward Ethnographies of Communication," American Anthropologist, 66 (6) (Special Issue: The Ethnography of Communication).

- (1971). Pidginization and Creolization of Languages. Cambridge University Press.

- (1972). "On Communicative Competence," Sociolinguistics. (eds.) J.B. Pride and J. Holmes. Harmondsworth: Penguin.

Irvine, J.T. (1985). "Status and Style in Language," Annual Review of Anthropology, 14:557-81.

- (1989). "When Talk Isn't Cheap: Language and Political Economy," American Ethnologist, 16(2):248-67.

Jacquemet, M. (1994). "T-offenses and Metapragmatic Attacks: Strategies of Interactional Dominance," Discourse and Society, 5(3):297-319.

- (1996). Credibility in Court. Cambridge University Press.

Jakobson, R. (1960). "Closing Statement: Linguistics and Poetics," Style and Language, (ed.) Sebeok, T. Cambridge, Mass: MIT Press.

Limon, J.E., and Young, M.J. (1986). "Frontiers, Settlements, and Development in Folklore Studies, 1972-1985," Annual Review of Anthropology. 15:437-60.

Leifer, E. M. (1991). Robust Action. New York: Garland.

Lodge, R.A. (1993). French: From Dialect to Standard. London: Routledge.

March J (1994). A Primer on Decision Making: How Decisions Happen. The Free Press: New York, NY. 
REDES- Revista hispana para el análisis de redes sociales

Vol. 18,\#13, Junio 2010

http:// revista-redes. rediris.es

Mohr, J. W. and White, H. C. (2008). "How to Model an Institution," Theory and Society, 37(5): 485-512.

Peirce, C. S. (1931). Collected Papers. C. Hartshorne \& P. Weiss (eds.) Cambridge, MA: Harvard University Press.

Podolny, J. M. (2001). "Networks as Pipes and Prisms of the Market," American J ournal of Sociology, 107(1):33-60.

Sacks, H., Schegloff, E.A., \& Jefferson, G. (1974). "A Simplest Systematics for the Organization of Turn-Taking for Conversation," Language, 50(4):696-735.

Sankoff, G. (1980). The Social Life of Language. Philadelphia, PA: University of Pennsylvania Press.

Sankoff, G. and Brown, P. (1976). "The origins of syntax in discourse: a case study of Tok Pisin Relatives," Language, 52(3):631-66

Schutz, A. (1970). On Phenomenology and Social Relations. (ed.) H. R. Wagner. The University of Chicago Press.

Silverstein, M. (1976). "Shifters, Verbal Categories and Cultural Description," in Meaning in Anthropology, (eds.) K. Basso and H. Selby. University of New Mexico Press.

- (1993). "Metapragmatic Discourse and Metapragmatic Function," Reflexive Language: Reported Speech and Metapragmatics. (ed.) J. Lucy. Cambridge University Press.

Stoeltje, B.J. and Bauman, R. (1988). "The Semiotics of Folkloric Performance," in The Semiotic Web 1987. T.A. Sebeok, \&J. Umiker-Sebeok. Berlin: deGruyter

Swales, J.M. (1990). Genre Analysis. Cambridge University Press.

Uhlenbeck, E.M. (1970). "The Use of Respect Forms in Javanese," Pacific Linguistic Studies in Honour of Arthur Capell. (ed.) S.A. Wurm and D.C. Laycock. Canberra: Linguistic circle of Canberra.

Volosinov, V.N. (1973 [1929]). Marxism and the Philosophy of Language. Seminar Press.

White, H. C. (1992). Identity and Control: A Structural Theory of Social Action. Princeton, NJ: Princeton University Press. 
REDES- Revista hispana para el análisis de redes sociales

Vol. 18,\#13, Junio 2010

http: // revista-redes. rediris.es

- (1995a). "Network Switchings and Bayesian Forks: Reconstructing the Social and Behavioral Sciences," Social Research, 62(4): 1035-1063.

- (1995b). "Talking is in Networks; Switches are via Publics," Manuscript. Paul F. Lazarsfeld Center for the Social Sciences at Columbia University.

- (1995c). "Times from Reflexive Talk," Manuscript. Paul F. Lazarsfeld Center for the Social Sciences at Columbia University.

- (2007). "Networks and Meaning: Styles and Switchings" Manuscript. A Plenary address for the Luzern Conference Commemorating Niklas Luhmann

- (2008). Identity and Control: How Social Formations Emerge. Princeton, NJ: Princeton University Press.

White, H. C., Godart, F. C. and Corona, V. P. (2007). "Mobilizing Identities: Uncertainty and Control in Strategy." Theory, Culture \& Society, 24:181-202.

Williams, R. (1977). Marxism and Literature. Oxford University Press. 